\title{
Deforestation and mosquito-borne diseases: another 'wake-up call' to
}

\section{Latin America}

Pedro M $M^{a}$ ALARCÓN-ELBAL ${ }^{1}$

A recent research conducted in Panama and published in Nature's Scientific Reports focused on the importance of conserving the old-growth forest in tropical rainforests as a highly recommended solution for preventing outbreaks of arboviral and parasitic diseases in anthropic environments. This fact is based on the positive effect that has forest disturbance on the abundance of colonist mosquito (Diptera: Culicidae) species, which are capable to thrive in altered forest sites and consequently might increase the risk of vector-borne disease emergence [1]. One more piece of evidence about a casuistry on which scientist has been warning for decades.

The disease emergence process appears to be associated with a combination of several complex variables. In a growing interconnected world, not only climate and sociodemographic factors influence the incidence of infectious diseases; the role of environmental factors such as deforestation, agricultural development, water projects and urbanization has also a great importance [2]. This epidemiological complexity increases in the case of vector-borne diseases, where several thriving organisms with outstanding ecological plasticity - most winged - can carry numerous pathogens around the world, taking in account that these diseases were among the most important global public health problems [3]. Specifically vector-borne zoonotic diseases, such as West Nile fever and yellow fever, involve even more complex relationships.

In the other hand, deforestation defined as a decrease in forest cover is the result of the expansion of the agricultural frontier, cattle ranching, illegal logging, forest and agricultural fires, infrastructure projects and mineral extraction [4]. Despite being a practice as old as human civilization, the rate of destruction, particularly of tropical rainforest, has increased dramatically since the second half of past century [5]. Deforestation influence health in many ways: releases $\mathrm{CO} 2$ to the atmosphere, which exerts a warming influence on Earth's climate, changes the land surface albedo and the evapotranspiration and rainfall patterns, and is a major cause of biodiversity loss by destroying habitats [6]; among other devastating effects. The problem is such that loss of forests remains one of the biggest environmental challenges in Latin America, as revealed in recent data showing that, far from stopping, tropical deforestation is continuously increasing in some regions, including the Brazilian Amazon Basin [7], one of the places most severely affected on the planet.

The relationship between deforestation and mosquito-borne diseases was first noticed in the middle of the last century for many researchers in some countries of Africa, Asia and America. In our continent the first evidence of this linkage took place in the 1930s to 1940s, when forested areas in Trinidad were cleared for cocoa plantations, which were soon colonized by Anopheles bellator, a species that caused malaria outbreaks in the cocoa estates [8]. In the Brazilian Amazon, in the past few decades, deforestation and environmental changes has led to a proliferation of Anopheles darlingi, a mosquito that replaced some other autochthonous species that were present before the forests were cut down, increasing the rates of this parasitic disease [9]. Taking into account the recent yellow fever outbreak in the country; and as noted years before for some Brazilian researchers [10], deforestation and expanding urban sprawl seem to be the main causes in the reduction of monkey habitat, especially in the southeastern state of Minas Gerais, reason why the arbovirus reached human populations mostly

\footnotetext{
${ }^{1}$ Universidad Iberoamericana, Instituto de Medicina Tropical \& Salud Global. Av. Francia, 129, Gazcue, Santo Domingo, Dominican Republic. Correspondence to: PM ALARCÓN-ELBAL. E-mail: <pedro.alarcon@uv.es>. 
throughout the bites of Haemagogus mosquitoes [11].

This later is not confined to Brazil or even South America and threatens other regions; sadly such as the island where I am writing these words: La Española. Haiti has experienced severe degradation of its natural resources and a significant change in its land cover in the last decades due, among other factors, to illegal harvesting of trees for the production of firewood and charcoal. The problem also affects the Dominican Republic, being especially notorious in areas of great ecological importance such as the forests of the Sierra de Bahoruco, the Dominican national park on the border of Haiti [12]. Understanding how this environmental impact can affect the transmission of mosquito-borne diseases - some of them endemic in the island, such as malaria or dengue - in the short term should be a goal of health authorities and research and academic centers.

Today anthropogenic impact, deforestation and arthropod-borne diseases remain largely associated with tropical regions but have impacts that extend globally, perhaps because Lovelock's Gaia hypothesis - which describes the Earth as a single giant living system - may not be so far-fetched. In consequence, there is a need to integrate autecology and synecology with landscape ecology to allow a better understanding of the interactions between organism populations and environment, besides promoting a stronger environmental consciousness in society, emphasizing especially in our governments.

\section{REFERENCES}

1. Loaiza JR, Dutari LC, Rovira JR, Sanjur OI, Laporta GZ, Pecor J, et al. Disturbance and mosquito diversity in the lowland tropical rainforest of central Panama. Sci Rep. 7(1):7248. doi: 10.1038/ s41598-017-07476-2

2. Patz JA, Githeko AK, McCarty JP, Hussein S, Confalonieri U, de Wet N. Climate change and infectious diseases. In: McMichael AJ, Campbell-Lendrum DH, Corvalán CF, Ebi KL, Githeko AK, et al. editors. Climate change and human health: risks and responses. Geneva: World Health Organization; 2003.

3. Gubler DJ. The global emergence/resurgence of arboviral diseases as public health problems. Arch Med Res. 2002;33(4):330-342.

\section{doi: $10.1016 / 50188-4409(02) 00378-8$}

4. Armenteras D, González TM, Luque-Moreno F, Rodríguez $\mathrm{N}$, Argotty F, Bonfil C, et al. IBERO REDD+. Red CYTED para el monitoreo del estado de la conservación y recuperación de bosques húmedos y secos en Latinoamérica en el contexto de la deforestación evitada. Síntesis de avances en la implementación de REDD + en los países participantes de la Red IBERO REDD+ en América Latina. Red IBERO-REDD+; 2015.

5. FAO. Global forest resources assessment 2000. Rome: Food and Agricultural Organization; 2000.

6. Bala G, Caldeira K, Wickett M, Phillips TJ, Lobell DB, Delire C, et al. Combined climate and carbon-cycle effects of large-scale deforestation. PNAS. 2007;104(16):6550-6555. doi: 10.1073/ pnas.0608998104

7. Instituto Nacional de Pesquisas Espaciais (INPE). 2016. PRODES estima $7.989 \mathrm{~km} 2$ de desmatamento por corte raso na Amazônia em 2016 [Internet]; Ministério da Ciência, Tecnologia, Inovações e Comunicações (Brazil); 2016 [cited 2018 Feb 15]. Available from: http://www.inpe.br/noticias/noticia.php?Cod_ Noticia $=4344$

8. Downs WG, Pittendrigh CS. Bromeliad malaria in Trinidad, British West Indies. Amer J Trop Med Hyg. 1946;26(1):47-66. doi: 10.4269/ajtmh.1946.s1-26.47

9. Barros FSB, Honório NA. Deforestation and Malaria on the Amazon Frontier: Larval Clustering of Anopheles darlingi (Diptera: Culicidae) Determines Focal Distribution of Malaria. Am J Trop Med Hyg. 2015;93(5):939-953. doi: 10.4269/ ajtmh.15-0042

10. da Costa Vasconcelos PF. Yellow fever in Brazil: thoughts and hypotheses on the emergence in previously free areas. Rev Saúde Pública. 2010;44(6).

11. Pan American Health Organization. 12 January 2018: yellow fever - epidemiological update. Washington, DC: PAHO; 2018.

12. Keel J, Mejia Botero J. Death by a thousand cuts [Internet]. 2016 [cited 2018 Feb 20]. Available from: http:// deathbyathousandcutsfilm.com/ 